American Journal of Applied Sciences 8 (4): 400-406, 2011

ISSN 1546-9239

(C) 2010 Science Publications

\title{
A Review of Static Tests and Recent Studies
}

\author{
Srilert Chotpantarat \\ Department of Geology, Faculty of Science, Chulalongkorn University, \\ 254 Phayathai Road, Pathumwan, Bangkok 10330, Thailand
}

\begin{abstract}
Problem statement: Acid mine drainage from waste rocks, tailings and other mine components, is one of the most important environmental concerns at mining sites. To attempt to determine the balance between the acid and neutralization potentials of the material and evaluate the possible acid-forming potential of mine waste, many static prediction tests have been developed to evaluate the acid-forming potentials of samples in recent years. Approach: This study attempts to highlight and summarize their essential issues and collates the mining projects that have used such static tests. Results: The advantages and disadvantages of each technique are compared to formulate and present guidelines for the appropriate selection and application of these tests. According to many studies, although several test methods have been modified in recent years, the ABA, NAG and paste $\mathrm{pH}$ methods are the most commonly static tests reported for initially indicating the acid-generating and neutralizing potential of samples. Conclusion/Recommendations: To provide confident acidforming predictions and consequently, the best waste management plans, at least several different techniques needs to be applied together in order to classify the acid generating potential of a sample more reliably.
\end{abstract}

Key words: Acid-forming potential, neutralization potential, acid mine drainage, mining areas, Acid Mine Drainage (AMD), sulfide minerals, Modified Acid Base Accounting (MABA), Acid Buffering Characteristics Curve (ABCC), acid-forming potentials, acid generation

\section{INTRODUCTION}

Mining industries are associated with Acid Mine Drainage (AMD), which is formed when sulfide minerals are oxidized on exposure to air and water in mine areas. The resultant acidification of the water from sulfur oxidation, coupled with oxidation itself, can lead to both chemical and microbial release of other pollutants and so mining areas can contain relatively high levels of toxic substances, such as cyanide, sulfate and potentially toxic heavy metals (i.e., $\mathrm{Pb}, \mathrm{Zn}, \mathrm{Cu}, \mathrm{Cd}$, $\mathrm{Fe}, \mathrm{Mn}$ and $\mathrm{Al}$ ), which can pose adverse long-term impacts on animals, human health and ecosystem degradation (Ardejani et al., 2010; Liang-qi et al., 2010; Perez-Lopez et al., 2007; Silvia and Zanetti, 2009; Unruh et al., 2009). Under an AMD situation, the release of such toxic substances can severely pollute the soil, surface and ground water systems (Alligui and Boutaleb, 2010; Mossad and Aral, 2010; Oprea et al., 2010; Ouangrawa et al., 2010; Rani and Chen, 2010). Although this process occurs naturally, mining industries may significantly accelerate AMD through disturbing the sulfide mineral and promoting their expose to water and oxygen. Moreover, some bacteria can naturally promote AMD generation, such as
Thiobacillus, which is capable of catalyzing iron oxidation at $\mathrm{pH}$ levels of 3.5-4.5 (Liang-qi et al., 2010; Jennings et al., 2008). The reactions of acid generation from the oxidation of pyrite $\left(\mathrm{FeS}_{2}\right)$, which is one of the most common sulfide minerals and precipitation of $\mathrm{Fe}$ hydroxides are shown in Eq. 1-4 below:

$$
\begin{aligned}
& 2 \mathrm{FeS}_{2}+\frac{7}{2} \mathrm{O}_{2}+\mathrm{H}_{2} \mathrm{O} \rightarrow \mathrm{Fe}^{2}+2 \mathrm{SO}_{4}{ }^{2-}+2 \mathrm{H}^{+} \\
& \mathrm{Fe}^{2+}+\frac{1}{4} \mathrm{O}_{2}+\mathrm{H}^{+} \rightarrow \mathrm{Fe}^{3}+\frac{1}{2} \mathrm{H}_{2} \mathrm{O} \\
& \mathrm{Fe}^{3+}+3 \mathrm{H}_{2} \mathrm{O} \rightarrow \mathrm{Fe}(\mathrm{OH})_{3(\mathrm{~s})}+3 \mathrm{H}^{+} \\
& 2 \mathrm{FeS}_{2}+14 \mathrm{Fe}^{3+}+8 \mathrm{H}_{2} \mathrm{O} \rightarrow 15 \mathrm{Fe}^{2+}+2 \mathrm{SO}_{4}^{2-}+16 \mathrm{H}^{+}
\end{aligned}
$$

As shown above, oxygen is an important oxidant of pyrite. The dissolved $\mathrm{Fe}^{2+}, \mathrm{SO}_{4}{ }^{2-}$ and $\mathrm{H}^{+}$represent an increase in the total dissolved solids and acidity of the water and sequentially induce a decrease in the $\mathrm{pH}$.

Due to variations in the mineralogy and geological formations from site-to-site and other factors affecting 
AMD generation, predicting the potential for AMD can be exceedingly challenging and costly (USEPA, 1994; Sapsford et al., 2009). Nevertheless, the prediction of AMD plays an important role in planning for mine waste management (Hesketh et al., 2010b) as the control of AMD to prevent or to inhibit acid production, by control of the acid migration or by treatment of AMD, can minimize the risk of any ongoing environmental liability from mining operations. Recently, various techniques have been developed to predict the Acid-Forming Potential (AFP) of mine waste materials, such as geological assessment, geochemical static tests and geochemical kinetic tests (Liao et al., 2007; Komnitsas et al., 2009; Hesketh et al., 2010b). Amongst these techniques, the static tests are popular as they are simple, rapid and inexpensive.

Therefore, this study consists of a brief review of recent static tests, one of the AMD prediction techniques, in the literature by comparing their advantages and disadvantages and the reagents used in each technique. The study also attempts to summarize recent studies in acid-forming prediction using static tests in mine sites between 1998 and early 2010 .

Acid generation prediction technique: Static tests Static tests are usually measured over a short time period of hours or days and are relatively low cost. They evaluate the balance between the acid generating and acid neutralizing capacity of a sample. Seven techniques are reviewed in this study, which determine the sample's maximum Acid Production Potential (APP) with its maximum Neutralization Potential (NP). These seven methods are (i) Acid-Base Accounting (ABA), (ii) Modified ABA (MABA), (iii) paste $\mathrm{pH}$, (iv) Net Acid Generation (NAG), (v) Sequential NAG test (SNAG), (vi) Kinetic NAG test (KNAG) and (vii) Acid Buffering Characteristics Curve (ABCC) test (Ehinola and Adene, 2008; Komnitsas et al., 2009; Hesketh et al., 2010b; Huges et al., 2007; Miller et al., 1991; Pope et al., 2010; Shu et al., 2001;; Weber et al., 2004). Each test uses separate methods to evaluate the capacity for acid generation and neutralization.

The assumption of static tests is the instant of acid production and neutralization potential. These tests are not used to predict the rate of acid-generating and acidconsuming minerals, but are only used for prediction of the APP. However, despite this limitation, static tests are quick and economical to perform and additionally have been reliably used as a tool for the evaluation of the AFP in mining areas in recent years. The seven selected static tests mentioned above are described as follows.
Acid-Base Accounting (ABA) method: The ABA test was developed in 1974 to evaluate coal mine waste and later was modified by Sobek et al. (1978). In the main, the ABA test has been applied in the United States and Canada. ABA methods are widely applied as a screening procedure for classifying samples according to their predicted AFP. The Maximum Potential Acidity (MPA) is determined from multiplication of the total sulfur contents by 30.59 (Bester and Vermeulen, 2010), which of course assumes that all of the sulfur present is reactive (i.e., pyritic sulfur). The Acid-Neutralization Capacity (ANC) was determined by a modified Sobek method (Sobek et al., 1978). Here, Hydrochloric Acid $(\mathrm{HCl})$ is added to the sample and then boiled until the reaction stops. The resulting cooled solution is back titrated to $\mathrm{pH} 7$ with $\mathrm{NaOH}$ to determine the amount of acid remaining and from this the amount of acid consumed in the reaction between $\mathrm{HCl}$ and the sample is deduced. A fizz test rating of the neutralization potential is used to select the $\mathrm{HCl}$ strength.

In Australia the ABA test is determined as the net acid producing potential (NAPP). This value is determined by subtracting the ANC from the MPA and is a measure of the difference between the NP and the AFP (Bester and Vermeulen, 2010). The NAPP is expressed in the units of $\mathrm{kg} \mathrm{H}_{2} \mathrm{SO}_{4} / \mathrm{t}$ of sample (Weber et al., 2004) and may be either negative or positive. The NAPP and/or the ratio of acid-NP to APP, is then compared with criteria values of classification to divide samples into categories. Materials with sulphide minerals, which have a NAPP (MPA-ANC) value of higher than 20 are likely to be an acid drainage source.

\section{Advantages:}

- It is a simple technique, takes a short time to perform, requires no special equipment, is easy to interpret and many samples can be tested (Bradham and Caruccio, 1990)

- It is relatively inexpensive and with a relatively high throughput can be used for processing large sample numbers

\section{Disadvantages:}

- The total sulfur is evaluated by Leco furnace, which measures all sulfur-bearing forms, including sulfides, sulfates and the organic sulfur in the sample. So, the MPA in the sample may be overestimated. Thus, there is the need to determine the organic sulfur, sulfate, sulfur and pyritic sulfur 
separately so as to be able to estimate the APP of each sample

- This method does not account for a kinetic rate (Bradham and Caruccio, 1990)

- If the MPA and ANC values are close, it is hard to interpret (Deopker and OConnor, 1991)

- Different particle sizes are not reflected (Deopker and OConnor, 1991)

- The ANC is affected by Fe carbonates, such as siderite $\left(\mathrm{FeCO}_{3}\right)$ and its presence may result in over estimation of the effective acid neutralization mineral content in that sample

Modified Acid Base Accounting (MABA) method: (Ehinola and Adene, 2008). This MABA method calculates the MPA based on the sulfide content, which is different from the total sulfur analyzed in the ABA test above in that the sulfur contribution from nonsulfide sources is excluded. The ANC is determined by using a longer $(24 \mathrm{~h})$ acid digestion at room temperature. Then, the sample is back titrated with sodium hydroxide to determine the acid consumed in the digestion, but with an endpoint of $\mathrm{pH} 8.3$ instead of the $\mathrm{pH} 7$ used in the ABA method.

Advantages: It is a simple technique, takes a short time, requires with no special equipment, is easy to interpret and many samples can be tested (Bradham and Caruccio, 1990).

\section{Disadvantages:}

- This method does not account for a kinetic rate (Bradham and Caruccio, 1990)

- If the MPA and ANC values are close, it is hard to interpret (Deopker and OConnor, 1991)

- Different particle sizes are not reflected (Deopker and OConnor, 1991)

- If jarosite or other acid producing sulfate minerals is present, this test may underestimate the available MAP (USEPA, 1994)

Paste pH method: The paste $\mathrm{pH}$ method is used to measure a mixture of soil and deionized water that form a slurry or paste together (Pope et al., 2010). The airdried sample is mixed with deionized water at a 1:1 $(\mathrm{w} / \mathrm{w})$ ratio and the $\mathrm{pH}$ is then measured with a $\mathrm{pH}$ meter, calibrated at $\mathrm{pH} 4.00-7.00$. Commonly, the paste conductivity, redox potential and Total Dissolved Solid (TDS) contents are also measured simultaneously with the paste $\mathrm{pH}$. Samples with a paste $\mathrm{pH}$ of less than 4.0 are considered as potentially APP.

\section{Advantages:}

- It is relatively inexpensive and can be used to assay a large amount of samples

- It is a simple and common field and bench scale test

- It takes a short time (ca. 15 min.) to determine the acid generation (Pope et al., 2010; Hughes et al., 2007)

\section{Disadvantages:}

- This method does not account for a kinetic rate (Bradham and Caruccio, 1990; Nugraha et al., 2009)

- This method needs to be combined with other techniques for estimating the acid-forming potential (Hughes et al., 2007)

Net Acid Generation (NAG) or net acid production test: In the NAG test, hydrogen peroxide $\left(\mathrm{H}_{2} \mathrm{O}_{2}\right)$ is used to accelerate the oxidation of sulfide (Saria et al., 2006; Nugraha et al., 2009). The reaction generates both acid and acid neutralization simultaneously. The final result represents the net acidic amount generated by the sample. This test differs from the ABA method described above in that it does not determine separately both the MPA and ANC, but rather determines a single value, NAPP.

To determine the NAG, $2.5 \mathrm{~g}$ of sample is oxidized by suspension in $250 \mathrm{~mL}$ of $15 \%(\mathrm{v} / \mathrm{v}) \mathrm{H}_{2} \mathrm{O}_{2}$, placed inside a fume hood for $24 \mathrm{~h}$ and then boiled for $1 \mathrm{~h}$. After cooling to ambient temperature, the final NAG $\mathrm{pH}$ is then measured and titrated using $0.1 \mathrm{~mol} / \mathrm{l} \mathrm{NaOH}$ to $\mathrm{pH} 4.5$ and $\mathrm{pH}$ 7. The NAG is calculated in terms of $\mathrm{kg} \mathrm{H}_{2} \mathrm{SO}_{4} / \mathrm{t}$ of sample (Shu et al., 2001). Commonly, a NAG pH of less than 4.5 indicates the sample is acid producing and the amount of acid is determined by back-titration and expressed in terms of $\mathrm{kg} \mathrm{H}_{2} \mathrm{SO}_{4} / \mathrm{t}$ of sample, similar to the ABA technique.

The NAG and ABA tests are usually used together to classify the acid generating potential of a sample ( Hesketh et al., 2010b; Nugraha et al., 2009).

Advantage: This test is relatively inexpensive for determination and can be applied to a large numbers of samples. 
Disadvantage: The complete decomposition of $\mathrm{H}_{2} \mathrm{O}_{2}$ in the test may occur before all the reactive sulfides have oxidized. Subsequently, the acidity potential may underestimate the APP. Therefore, the use of the NAG test alone may not reveal the actual total APP of samples (USEPA, 1994).

Sequential NAG test (SNAG): The SNAG test was developed to overcome the effect of the incomplete oxidation of sulphide, which typically occurs when the pyritic sulfur content is greater than $0.7-1 \%$ of the total sulfur content and simply involves a series of additions of $15 \%(\mathrm{v} / \mathrm{v}) \mathrm{H}_{2} \mathrm{O}_{2}$ to the same sample. At the end of each NAG test stage, the mixture sample is filtered and then the NAG $\mathrm{pH}$ and titrated acidity are measured. The NAG test is then repeated in the same manner until the NAG $\mathrm{pH}$ is $\geq 4.5$. All of the individual NAG acidities are summed to estimate a total SNAG acidity in the terms of $\mathrm{kg} \mathrm{H}_{2} \mathrm{SO}_{4} / \mathrm{t}$ of sample. Then, the SNAG solutions are filtered, pooled and made up to the original $250 \mathrm{ml}$ with deionized water in order to account loss by evaporation, prior to being analyzed for sulfur content by ICP-OES (Hesketh at al., 2010a).

\section{Advantages:}

- It provides a better estimation of the total APP of samples than the NAG test

- It provides a snapshot of the balance between the acid production and acid neutralization during the procedure

Disadvantage: It takes a much longer time than the NAG test.

Kinetic NAG test (KNAG): The KNAG test is applied to evaluate the lag time that may be experienced by any given material type before acid generation begins. To carry out the KNAG test, 250 $\mathrm{mL}$ of $15 \%(\mathrm{v} / \mathrm{v}) \mathrm{H}_{2} \mathrm{O}_{2}$ is added to the sample $(1 \mathrm{~g})$ and the $\mathrm{pH}$ and temperature of the NAG liquor are monitored throughout the test. The Electrical Conductivity (EC) of the NAG liquor may also optionally be monitored.

Advantage: It can evaluate the lag period and oxidation rates as with leached column tests but in a shorter time.

\section{Disadvantages:}

- It takes a much longer time than the NAG test

- Samples in which pyrite armoring inhibits the oxidation under leach column conditions result in longer column lags than those estimated by the KNAG test

- Samples with a neutralizing phase of low reactivity, which are not ready for acid buffering in the short period of NAG tests but are available in the longer time in column tests, consequently yield longer column lag times than those predicted by the KNAG technique

Acid Buffering Characteristics Curve (ABCC): The $\mathrm{ABCC}$ test is an alternative to the ANC procedure, but takes a longer time to complete than the ANC test and involves a slow titration of a given sample with continuous monitoring of the $\mathrm{pH}$ values. The shape of the acid $\mathrm{ABCC}$ profile provides an indication on the availability for acid neutralization. When ANC values affected by siderite, the ABCC will show very shape drop with sequential acid additions. The test can be carried out as follows: the addition of water to the sample at a $2 \%(\mathrm{w} / \mathrm{v})$ ratio and then the slow titration with $\mathrm{HCl}$ with continuous stirring until the mixture reaches $\mathrm{pH}$ 3. The volume and concentration of $\mathrm{HCl}$ at each addition is varied according to set ANC ranges and the time of successive additions is kept constant at approximately $15 \mathrm{~min}$. High $\mathrm{HCl}$ volumes and concentrations are added for high ANC samples and low $\mathrm{HCl}$ volumes and concentrations are used for low ANC samples.

Advantage: 1. The ABCC test results effectively provide an indication of the relative resistivity of the ANC measured in waste rock samples, something not evident in ANC test results alone (i.e., Siderite).

Disadvantage: It takes a longer time per sample than the ANC method.

\section{AFP prediction using static tests in recent studies:} Evaluation of the AFP has been developed and applied for many mine projects throughout the world. A summary of the recent studies of AFP prediction using static tests is shown in Table 1. 
Am. J. Applied Sci., 8 (4): 400-406, 2011

Table 1: The mining sites used the static test methods to characterized the APP (Modified from Samuel, 2006)

\begin{tabular}{|c|c|c|c|}
\hline Site or Project & Location & Method & Reference \\
\hline$\overline{\mathrm{Pb}-\mathrm{Zn} \text { mine at Lechang }}$ & Guangdong, People's Republic of China & ABA, NAG test & Wong et al. (1998) \\
\hline Zortman and Landusky Mines & Phillips Country, Montana & Paste $\mathrm{pH}$, modified ABA & Shaw (2000); Shaw et al. (2000) \\
\hline New Zealand coal mine & New Zealand & Paste $\mathrm{pH}, \mathrm{ABA}$ & Campbell et al. (2001) \\
\hline $\begin{array}{l}\text { INAP Rock Pile } \\
\text { Ok Tedi Mine }\end{array}$ & Papua & $\begin{array}{l}\text { ABA, NAG kinetic and } \\
\text { sequential NAG }\end{array}$ & Rumble et al. (2003) \\
\hline Kaltim Prima Coal mine & Samarinda, Kalimantan, Indonesia & Paste $\mathrm{pH}, \mathrm{ABA}$ and kinetic NAG & Weber et al. (2004) \\
\hline $\begin{array}{l}\text { Coal mine (Three pit mine dumps: } \\
\text { FD, ND, OD) }\end{array}$ & Berau, East Kalimantan, Indonesia & $\mathrm{ABA}$ and $\mathrm{NAG}$ & Saria et al. (2006) \\
\hline Questa molybdenum mine & $\begin{array}{l}\text { Taos County, North central New } \\
\text { Mexico }\end{array}$ & Paste $\mathrm{pH}, \mathrm{ABA}, \mathrm{NAG}$ & Samuel (2006) \\
\hline Prestea and Bogoso mines & Ghana & ABA, NAG & Akabzaa et al. (2007) \\
\hline 17 mine sites & $\begin{array}{l}\text { Provinces of Guangdong, Hunan, } \\
\text { Gansu and Shanxi, China }\end{array}$ & Paste $\mathrm{pH}, \mathrm{NAG}$ & Liao et al. (2007) \\
\hline Stockton coal mine & South Island, New Zealand & Paste $\mathrm{pH}, \mathrm{ABA}$ & Hughes et al. (2007) \\
\hline Nigeria coal mine & Benue, Nigeria & Modified ABA & Ehinola and Adene (2008) \\
\hline Akara gold mine & Pichit Province, Thailand & $\mathrm{ABA}$ and $\mathrm{NAG}$ & Changul et al. (2009) \\
\hline PT. Kaltim Prima Coal (KPC) & Sengata-East Kalimantan, Indonesia & $\mathrm{ABA}, \mathrm{NAG}$ and Paste $\mathrm{pH}$ & Nugraha et al. (2009) \\
\hline Atikokan coal mine & Northwestern Ontario & $\mathrm{ABA}$ & Yeheyis et al. (2009) \\
\hline Waterberg coal mine & Limpopo Province, South Africa & ABA & Bester and Vermeulen (2010) \\
\hline Copper mine & South Africa & $\mathrm{ABA}$ and $\mathrm{NAG}$ & Hesketh et al. (2010b) \\
\hline $\begin{array}{l}\text { Brunner, Paparoa, Morley Coal } \\
\text { and Gore Lignite Measures }\end{array}$ & $\begin{array}{l}\text { West Coast and Southland, } \\
\text { New Zealand }\end{array}$ & ABA, NAG and Paste $\mathrm{pH}$ & Pope et al. (2010) \\
\hline
\end{tabular}

\section{CONCLUSION}

There are many static tests for characterizing the potential acid-forming prediction in mining sites. The commonly applied static tests yield information about the acid-forming generation and acid neutralization of samples. In recent years many techniques have been developed but deciding which are the most appropriate for any given number or type of samples requires taking into consideration many factors, including the geochemical and mineralogical characterization of the samples collected from the sites. Although many techniques have been developed, no single technique is ideal or likely to be accurate, but rather each technique needs to be used together with others to obtain a more reliable estimate of the acid generating potential of a sample. The KNAG test could be applied to evaluate the rate of the oxidation reaction of AMD with a shorter time, as compared with leached column tests.

\section{ACKNOWLEDGMENT}

The researchers are very grateful to the Ratchadaphiseksomphot Endowment Fund, Geology Department, Faculty of Science, Chulalongkorn University and the Research Strategic Plan (A1B1-2), Research Funds from the Faculty of Science, Chulalongkorn University for funding.

\section{REFERENCES}

Akabzaa, T.M., T.E.K. Armah and B.K. BaneongYakubo, 2007. Prediction of acid mine drainage generation potential in selected mines in the ashanti metallogenic belt using static geochemical methods. Environ. Geol., 52: 957-964. DOI: $10.1007 / \mathrm{s} 00254-006-0537-1$
Alligui, F. and A. Boutaleb, 2010. Impact of mercury mine activities on water resources at AzzabaNorth-East of Algeria. Am. J. Environ. Sci., 6: 395-401. DOI: 10.3844/ajessp.2010.395.401

Ardejani, F.D., B.J. Shokri, M. Bagheri and E. Soleimani, 2010. Investigation of pyrite oxidation and acid mine drainage characterization associated with Razi active coal mine and coal washing waste dumps in the Azad shahr-Ramian region, northeast Iran. Environ. Earth Sci., 61: 1547-1560. DOI: 10.1007/s12665-010-0469-7

Bester, M. and P.D. Vermeulen, 2010. Investigation of potential water quality and quantity impacts associated with mining of the shallow Waterberg coal reserves, west of the Daarby Fault, Limpopo Province, South Africa. Water SA 36: 531-542.

Bradham, W.S. and F.T. Caruccio, 1990. A Comparative Study of Tailings Analysis using acid/base Accounting, Cells, Columns and Soxhlets. Proceedings of the 1990 Mining and Reclamation Conference and Exhibition, April 2326 , Charleston. http://wvmdtaskforce.com/proceedings/90/90BRA/ 90BRA.HTM

Campbell, R.N., P. Lindsay and A.H. Clemens, 2001. Acid generating potential of waste rock and coal ash in New Zealand coal mines. Int. J. Coal Geol., 45: 163-179. DOI: 10.1016/S0166-5162(00)00031-8

Changul, C., C. Sutthirat, G. Padmanahban and C. Tongcumpou, 2009. Assessing the acidic potential of waste rock in the Akara gold mine, Thailand. Environ. Earth Sci., 60: 1065-1071. DOI: 10.1007/s12665-009-0251-x 
Deopker, R.D. and W.K. OConnor, 1991. Column leach study 1: Heavy metal dissolution characteristics from selected copper mine tailings. Mine Water Environ., 10: 57-71. DOI: 10.1007/BF02914809

Ehinola, O.A. and T.A. Adene, 2008. Preliminary investigation on acid generating potential of coals from Benue trough, Nigeria. Petroleum Coal, 50: 19-26.

Hesketh, A.H., J.L. Broadhurst and S.T.L. Harrison, 2010a. Mitigating the generation of acid mine drainage from copper sulfide tailings impoundments in perpetuity: A case study for an integrated management strategy. Miner. Eng., 23: 225-229. DOI: 10.1016/j.mineng.2009.09.020

Hesketh, A.H., J.L. Broadhurst, C.G. Bryan, R.P. van Hille and S.T.L. Harrison, 2010b. Biokinetic test for the characterisation of AMD generation potential of sulfide mineral wastes. Hydrometallurgy, 104: 459-464. DOI: 10.1016/j.hydromet.2010.01.015

Hughes, J., D. Craw, B. Peake, P. Lindsay and P. Weber, 2007. Environmental characterisation of coal mine waste rock in the field: An example from New Zealand. Environ. Geol., 52: 1501-1509. DOI: 10.1007/s00254-006-0594-5

Jennings, S.R., P.S.Blicker and D.R. Neuman, 2008. Acid Mine Drainage and Effects on Fish Health and Ecology: A Review. 1st Edn., Reclamation Research Group Publication, Bozaman, pp: 52.

Komnitsas, K., K. Manouski and D. Zaharaki, 2009. Assessment of reactivity of sulphidic tailings and river sludges. Geochemistry: Exploration, Environmental, Analysis, 9: 313-318. DOI: 10.1144/1467-7873/09-198

Liang-qi, L., S. Ci-an, X. Xiang-li, L. Yan-hong and W. Fei, 2010. Acid mine drainage and heavy metal contamination in groundwater of metal sulfide mine at arid territory (BS mine, Western Australia). Trans. Nonferrous Met. Soc. China. DOI : 10.1016/S1003-6326(09)60326-5

Liao, B., L.N. Huang, Z.H. Ye, C.Y. Lan and W.S. Shu, 2007. Cut-off net acid generation $\mathrm{pH}$ in predicting acid-forming potential in mine spoils. J. Environ. Qual., 36: 887-891. PMID: 17485720 Miller, S.D., J.J. Jeffery and J.W.C. Wong, 1991. Use and misuse of the acid-base account for AMD [acid mine drainage] prediction. (Utilisation et mauvaise utilisation du compte de base acide pour la prediction d'AMD). Proceedings of the 2nd International Conference on the Abatement of Acidic Drainage, Sept. 16, Ottawa, Ontaio, Canada, pp: 489-506.
Mossad, R. and H. Aral, 2010. Numerical modeling of flow in a horizontal sand filter. Am. J. Eng. Applied Sci., 3: 286-292. DOI: 10.3844/ajeassp.2010.286.292

Nugraha, C., H. Shimada, T. Sasaoka, M. Ichinose and K. Matsui et al., 2009. Waste rock characteristics at tropical coal mine area: A case study of PT. Kaltim Prima Coal, Indonesia. Int. J. JCRM, 5: 77-82.

Oprea, G.,A. Michnea, C. Mihali, M. Senila and C. Roman et al., 2010. Arsenic and antimony content in soil and plants from Baia mare area, Romania. Am. J. Environ. $\quad$ Sci., 6: 33-40. DOI: 10.3844/ajessp.2010.33.40

Ouangrawa, M., M. Aubertin, J.W. Molson, B. Bussiere, G.J. Zagury. 2010. Preventing acid mine drainage with an elevated water table: Long-term column experiments and parameter analysis. Water Air Soil Pollut., 213: 437-458. DOI: 10.1007/s11270-010-0397-x

Perez-Lopez, R., J.M. Nieto and G.R. de Almodovar, 2007. Utilization of fly ash to improve the quality of the acid mine drainage generated by oxidation of a sulphide-rich mining waste: Column experiments. Chemosphere, 67: 1637-1646. DOI: 10.1016/j.chemosphere.2006.10.009

Pope, J., P. Weber, A. Mackenzie, N. Newman and R. Rait, 2010. Correlation of acid base accounting characteristics with the Geology of commonly mined coal measures, West Coast and Southland, New Zealand. New Zeal. J. Geol. Geop. 53: 153-166. DOI: $10.1080 / 00288306.2010 .498404$

Rani, F.M. and Z.H. Chen, 2010. Numerical modeling of groundwater flow in Karst aquifer, Makeng mining area. Am. J. Environ. Sci. 6: 78-82. DOI: 10.3844/ajessp.2010.78.82

Rumble, C., S. Miller, H. Kundapen and B. Bolton, 2003. Evaluation of the sulfide and carbonate distribution in waste rock dumps and development of operational guidelines for acid rock drainage control at the Ok Tedi mine, Papua New Guinea. Proceedings of the 6th International Conference on Acid Rock Drainage, July 12-18, Cairns, Queensland, Australia, pp: 173-180.

Samuel, T.M., 2006. Characterization of the acidproducing potential and investigation of its effect on weathering of the goathill north rock pile at the Questa molybdenum mine, New Mexico. Master Thesis, New Mexico Institute of Mining and Technology, Department of Mineral Engineering, Socorro, New Mexico. http:/geoinfo.nmt.edu/staff/mclemore/documents/ Tachie-Menson2006Thesis.pdf 
Sapsford, D.J., R.J. Bowell, M. Dey and K.P. Williams, 2009. Humidity cell tests for the prediction of acid rock drainage. Miner. Eng., 22: 25-36. DOI: 10.1016/j.mineng.2008.03.008

Saria, L., T. Shimaoka, K. Miyawaki, 2006. Leaching of heavy metals in acid mine drainage. Waste Manage. Res. 24: 134-140. DOI: 10.1177/0734242X06063052

Shaw, S.C., 2000. Geochemical characterization and water quality predictions for the Zortman/Landusky Reclamation Project. Proceedings of the Conference on Mine Design, Operations and Closure, MDOC'00, Robertson, Robertson GeoConsultants Inc., Vancouver, BC, Canada, pp: 1-16.

Shaw, S.C., A.M. Robertson and W.C. Maehl, 2000. Material characterization and prioritization of remediation measures at the Zortman/Landusky mine sites. Proceedings of the Billings Land Reclamation Symposium, BLRS'00, Billings, Montana, USA. http://www.robertsongeoconsultants.com/publicati ons/billings99.pdf

Shu, W.S., Z.H. Ye, C.Y. Lan, Z.Q. Zhang and M.H. Wong, 2001. Acidification of lead/zinc mine tailings and its effect on heavy metal mobility. Environ. Int., 26: 389-394. DOI: 10.1016/S01604120(01)00017-4

Silvia, F. and M.C. Zanetti, 2009. Preliminary tests concerning zero-valent iron efficiency in inorganic pollutants remediation. Am. J. Environ. Sci., 5: 556-561. DOI: 10.3844/ajessp.2009.556.561
Sobek, A.A., W.A. Schuller, J.R. Freeman and R.M. Smith, 1978. Field and laboratory methods applicable to overburdens and minesoils. West Virginia University. http://www.techtransfer.osmre.gov/nttmainsite/Libr ary/hbmanual/fieldlab/front.pdf

Unruh, D.M., S.E. Church, D.A. Nimick and D.L. Fev. 2009. Metal contamination and post-remediation recovery in the Boulder River watershed, Jefferson County, Montana. Geochem.: Explor. Environ. Anal., 9: 179-199. DOI: 10.1144/1467-7873/09191

USEPA, 1994. Technical document: Acid mine drainage prediction. Office of Solid Waste, Washington. http://water.epa.gov/polwaste/nps/upload/amd.pdf

Weber, P.A., W.A. Stewart, W.M. Skinner, C.G. Weisener and J.E. Thomas et al., 2004. Geochemical effects of oxidation products and framboidal pyrite oxidation in acid mine drainage prediction techniques. Applied Geochem., 19: 1953-1974. DOI: 10.1016/j.apgeochem.2004.05.002

Wong, J.W.C., C.M. Ip and M.H. Wong, 1998. Acidforming capacity of lead-zinc mine tailings and its implications for mine rehabilitation. Environ. Geochem. Health, 20: 149-155. DOI: 10.1023/A:1006589124204

Yeheyis, M.B., J.Q. Shang and E.K. Yanful, 2009. Long-term evaluation of coal fly ash and mine tailings co-placement: A site-specific study. J. Environ. Manage., 91: 237-244. PMID: 19744768 